\title{
The Effects of Rapamycin and 3-Methyladenine on Nitric Oxide Synthase Enzymes in Cisplatin-Induced Neurotoxicity
}

\author{
Efectos de la Rapamicina y la 3-Metiladenina sobre la Enzima \\ Óxido Nítrico Sintasa en la Neurotoxicidad Inducida por Cisplatino
}

\author{
Emin Kaymak ${ }^{1}$; Derya Karabulut²; Emel Ozturk³; Ali Tugrul Akin4 \& Birkan Yakan²
}

KAYMAK, E.; KARABULUT, D.; OZTURK, E.; AKIN, A. T. \& YAKAN, B. The effects of rapamycin and 3-methyladenine on nitric oxide synthase enzymes in cisplatin-induced neurotoxicity. Int. J. Morphol., 39(2):659-666, 2021.

SUMMARY: The aim of this study was to determine the relationship of autophagy-enhancing rapamycin (RAPA) and autophagyinhibitor 3-methyladenine (3-MA) with Nitric oxide synthases (NOS) in Cisplatin (CIS)-induced neurotoxicity in rats. Rats were divided into 4 groups ( $\mathrm{n}=10)$ : Control was applied saline, CIS (a single dose of $8 \mathrm{mg} / \mathrm{kg}$ intraperitoneal (i.p.) on $7^{\text {th }}$ day of experiment), RAPA+CIS ( $2 \mathrm{mg} / \mathrm{kg} /$ i.p. RAPA per day and $8 \mathrm{mg} / \mathrm{kg} /$ i.p. CIS on $7^{\text {th }}$ day), 3-MA+CIS (15 mg/kg/i.p. 3-MA per day and $8 \mathrm{mg} / \mathrm{kg} / \mathrm{i} . \mathrm{p}$. CIS on $7^{\text {th }}$ day). Rats were sacrificed under anesthesia. Brain tissues were evaluated histopathologically. eNOS, Inos, nNOS and MAP 2 immunostaining were performed to determine the expression levels of these proteins among groups. Superoxide dismutase (SOD), Catalase (CAT), Malondialdehyde (MDA) and Interleukin IL-6 levels in brain tissue and serum nitric oxide (NO) level were measured by ELISA assay. In histopathological evaluation, neurodegeneration was seen in the CIS group. There was an increase in eNOS, iNOS and nNOS immunostaining in CIS group. While MAP2 immunostaining of the CIS group decreased. There was a decrease in SOD and CAT levels of brain tissue in CIS group. However, there was an increase in MDA, IL-6 and NO levels of brain tissue in CIS group. We found that antioxidant capacity increase while, inflammation and nitric oxide levels decreased in the RAPA-treated group. 3-MA does not have a significant effect. We suggest that CIS-induced neurotoxicity is more effective than Rapa 3-MA and may also be linked to NOS enzymes.

KEY WORDS: Antioxidant; Cisplatin; Rapamycin; 3-Methyladenine; Nitric oxide.

\section{INTRODUCTION}

Cisplatin (CIS), also called Cisdiamminedichloroplatinum (II), is white or ocher to yelloworange crystalline powder at room temperature. Because it has anticancer activity, CIS is used in various types of cancer such as lung, breast, ovarian, testicle and head and neck cancers. It is the most widely known cancer drug among chemotherapy drugs (Dasari \& Tchounwou, 2014; Hanif \& Hartinger, 2018). Although CIS is used in many cancer treatments, it has many side effects (Quintanilha et al., 2017). These include damages such as neurotoxicity, nephrotoxicity, hepatotoxicity, spermatotoxicity ( $\mathrm{Lu}$ et al., 2006; Melli et al., 2008; Santos et al., 2008; Kohsaka et al., 2020). Chemotherapeutic drugs lead to functional impairment in neurons through oxidative stress, inflammation, apoptosis ( $\mathrm{N}$ et al., 2019). It has been stated that CIS causes reactive oxygen species (ROS) and lipid peroxidation to increase in the nervous system (Chen et al., 2019; N et al., 2019).ROS, which occurs in brain damage, has been shown to stimulate oxidative stress, apoptosis and necrosis (Zuo et al., 2018; Chen et al.). CIS has been shown to increase IL-6 expression from inflammatory markers (Chen et al.). CIS treatment has been shown to reduce antioxidant capacity and lead to apoptosis (Park et al., 2008; Unel \& Erol, 2018).

Nitric oxide (NO) is a pre-inflammatory mediator produced by three different nitric oxide synthase enzymes (NOSs). These enzymes are called endothelial NOS (eNOS), inducible NOS (iNOS), and neuronal NOS (nNOS). Neuronal NOS (nNOS) is produced by neurons of the central nervous system (Fang et al., 2017; Zuo et al.). Studies have shown that these three NOS and NO amount increase in brain damage (Fang et al.; Qin et al., 2018). Microtubule-

\footnotetext{
${ }^{1}$ Histology-Embryology Department, Faculty of Medicine, Yozgat Bozok University, Adnan Menderes Street, 66200, Azizli, Yozgat, Turkey.

${ }^{2}$ Histology-Embryology Department, Faculty of Medicine, Yenidogan, Turhan Baytop Street, 38280 Talas, Erciyes University, Kayseri, Turkey.

${ }^{3}$ Histology-Embryology Department, Faculty of Medicine, Harran University, S anllurfa-Mardin Highway Over 18.Km, 63300, S anliurfa, Turkey.

${ }^{4}$ Biology Department, Faculty of Science, Erciyes University, Yenidogan, Turhan Baytop Street No:1, 38280 Talas, Kayseri, Turkey.
} 
associated protein 2 (MAP 2) is an important marker in brain injury studies (Yu et al., 2019). In brain injury studies, the level of MAP-2 has been shown to be reduced (Raber et al., 2018; Pérez-Corredor et al., 2020).

Microtubules are the main structural components of the neuronal cytoskeleton and have an important role in the preparation of axons and dendrites. MAP 2 plays an important role in neuronal morphogenesis. MAP-2 provides stability of microtubules and creates cross-link structure of microtubules (Fontaine-Lenoir et al., 2006). Neurotoxicity studies have shown that the amount of MAP-2 decreases in the brain and MAP-2 is an important marker in neurotoxicity (Yu et al.).

Rapamycin (RAPA) is a fermentation product derived from Streptomyces hygroscopicus isolated from the soil sample collected on Easter Island in 1976. It was originally characterized as a macrolide antibiotic with antifungal properties. The autophagy activator RAPA has other potential therapeutic properties, including antitumor activity, neuroprotective and neuroregenerative effects, prolongation and anti-atherosclerotic effects. RAPA has been shown to reduce ROS production and the amount of IL-6 (Schmitz et al., 2008; Cappoli et al., 2019).

3-Methyladenine (3-MA) is known as an autophagy inhibitor (Xu et al., 2012). It has also been shown in studies to increase ROS production (Cao et al., 2017; He et al., 2019). It has been shown that apoptosis, inflammation and oxidative stress increase with suppression of autophagy $(\mathrm{Xu}$ et al., 2018). 3-MA has been shown to inhibit autophagy in brain damage studies, thereby preventing damage reduction (Li et al., 2017). 3-MA has been shown to increase inflammation and apoptosis in neurons and microglia in the brain (Jin et al., 2017).

However, the effect of rapamycin and 3methyladenine on NOS in Cisplatin-induced neurotoxicity has not been described. In this study, we aimed to show whether NOS enzymes are affected by applying autophagy activator and inhibitor in CIS-induced brain injury. In addition, we performed the evaluation of the damage to the brain tissue through biochemical parameters and the relationship between NOS enzymes and MAP-2.

\section{MATERIAL AND METHOD}

Experimental procedure. This study was planned and performed in Erciyes University Faculty of Medicine Histology-Embryology Department in line with the approval of the Ethics Committee of Erciyes University Experiments Local Ethics Committee. All procedures were carried out in accordance with the Universal Declaration of Animal Rights, with the approval of the. In this study all the animals received human care according to standart guidelines. The experimental stage of the study was carried out in the Erciyes University Experimental Research Application and Research Center (DEKAM).

In this study, 8-week-old 150-200 g adult 40 Wistar albino type male rats produced in DEKAM were used. Rats kept in cages were kept in the normal order of the day at 21 ${ }^{\circ} \mathrm{C}$ and 12 hours of light / dark environment and water and nutrient needs were provided. The experimental groups were formed by weighing the subjects and putting them together so that their weights were close to each other.

Group I ( $\mathrm{n}=10)$ : Control group injected was applied saline throughout the experiment to this group.

Group II ( $\mathrm{n}=10)$ : Cisplatin (CIS) group injected with a single dose of $8 \mathrm{mg} / \mathrm{kg} /$ i.p. Cisplatin on the 7 th day of experiment.

Group III ( $\mathrm{n}=10)$ : Rapamycin (RAPA) $2 \mathrm{mg} / \mathrm{kg} / \mathrm{i} . \mathrm{p}$. (dissolved in ethanol+dH2O) throughout the experiment + Cisplatin (CIS) injected with a single dose of $8 \mathrm{mg} / \mathrm{kg} /$ i.p. Cisplatin on the 7th day of experiment.

Group IV (n=10): 3-methyladenine (3-MA) $15 \mathrm{mg} / \mathrm{kg} / \mathrm{i} . \mathrm{p}$. (dissolved in ethanol+dH2O) throughout the experiment + Cisplatin (CIS) injected with a single dose of $8 \mathrm{mg} / \mathrm{kg} / \mathrm{i} . \mathrm{p}$. Cisplatin on 7th day of experiment.

Experiment continued for $\mathbf{1 5}$ days. At the end of the experiment, animals were anesthetized with $30 \mathrm{mg} / \mathrm{kg}$ ketamine and $4 \mathrm{mg} / \mathrm{kg}$ xylazine and they were sacrificed; brain tissues and serum were taken for histopathological, immunohistochemical and biochemical evaluation.

Chemicals and drugs. Antibodies were obtained eNOS (bs0163R, Bioss, Boston, MA, USA), iNOS (bs-2072R, Bioss, Boston, MA, USA), nNOS (PA3032A, Thermo Fisher Scientific) and MAP-2 (MAP-2 (A-4): sc-74421, Santa Cruz Biotechnology). Drugs were obtained Rapamycin (CAS\#53123-88-9, LC Laboratories) and 3-methyladenine (Cat. No: m9281, Sigma Aldrich).

Histopathological evaluation. Brain tissues were placed in a $10 \%$ formalin fixation solution for histological examination. After $10 \%$ formalin fixation, brains were passed through gradually increasing alcohol series. It was then placed in xylene. Brain tissues waiting in liquid paraffin 
are then embedded in paraffin. Brain sections of $5 \mathrm{~mm}$ from paraffin blocks were left in the oven for a certain period of time using histological methods, then paraffin was removed with xylene and passed through graduated alcohol series and diluted. Sections hematoxylin and eosin (H\&E) staining was performed to see the general histological structure. The slides were then examined under an Olimpus BX53 microscope.

Immunohistochemistry. Immunohistochemistry method was used to investigate, eNOS, iNOS, nNOS and MAP-2 antibodies in brain tissues. Avidin biotin peroxidase method was used to determine the difference in expression of, eNOS, iNOS nNOS and MAP-2 in brain sections. Paraffin sections were deparaffinized in xylene. For antigen recovery, $0.01 \mathrm{M} 10 \%$ citrate buffer (pH: 6.0) was applied in the microwave for $7 \mathrm{~min}$ at $600 \mathrm{w}$ and then allowed to cool at room temperature for $10 \mathrm{~min}$. Sections washed with phosphate buffer (PBS) were treated with $3 \%$ hydrogen peroxide (H2O2) for 12 min to prevent endogenous peroxidase activity. It was washed again with PBS 3 times for $5 \mathrm{~min}$. The staining kit (TA-125-HDX, Thermo Fisher Scientific, Waltham, MA, USA) was used for the next steps. After washing again 3 times in PBS, ultra $v$ block solution was added to the tissues and kept in the tank for $10 \mathrm{~min}$. After then, eNOS, iNOS, nNOS and MAP-2 antibodies were added to the tissues and incubated overnight at $4{ }^{\circ} \mathrm{C}$. After re-washing, the peroxidase in the kit, which exhibits diaminobenzidine (DAB) (TA-060-HDX, Thermo Fisher Scientific, Waltham, MA, USA), was treated with the peroxidase substrate for $1.5 \mathrm{~min}$ to make its immunoreactivity visible. Lastly, the sections that were dehydrated by immersion in graded series of alcohol (70 $\%, 80 \%, 96 \%, 100 \%$ ) were passed through xylene and covered with Entellan ${ }^{\circledR}$, Merck, a rapid mounting medium and observed under Olympus BX53 microscope. Image J program was used to evaluate antibody expressions (Karabulut et al., 2016).
Biochemical Analysis. Brain tissues from subjects were raised to $-80{ }^{\circ} \mathrm{C}$. Tissues were homogenized before study. Then, centrifugation was applied and supernatants were transferred to Eppendorf tubes for use. By ELISA method Superoxide dismutase (SOD) (Cat. No: 201-11-0169, Sun Red Biological Technology), Catalase (CAT) (Cat. No: 20111-5106, Sun Red Biological Technology), Malondialdehyde (MDA) (Cat. No: Cat. No: 201-11-0157, Sun Red Biological Technology), Interleukin IL-6 (Cat. No: Cat. No: 201-110136, Sun Red Biological Technology) and nitric oxide (NO) (Cat. No: Cat. No: E0703Ra, Bioassay Technology Laboratory) kits were used and quantities were determined in $\mathrm{ng} / \mathrm{ml}$ at $450 \mathrm{~nm}$ in ELISA reader.

Ethical Committee. (Date: 12.12.2018, Decision no: 18/ 161) of Erciyes University Experimental Animals.

Statistical analysis. The Kolmogorov-Smirnov test was used to identify the normal distribution of the data. One-way analysis of variance and posthoc Tukey test were used to determine differences between groups. Results are presented as mean \pm SD. The SPSS/PC program (Version 20.0; SPSS, Chicago, IL) and Graphpad Prism 8.0 software was used for statistical analysis. $\mathrm{P}<0.05$.were considered as statistically significant.

\section{RESULTS}

Histopathological results. In brain tissue was performed H\&E performed to investigate the histopathological changes. In the Control and RAPA+CIS groups was observed healthy histological brain tissue. In CIS and 3-MA + CIS groups, it was observed that necrotic cells, pycnotic nuclei and perineural edema increased in the brain compared to other groups (Fig. 1).
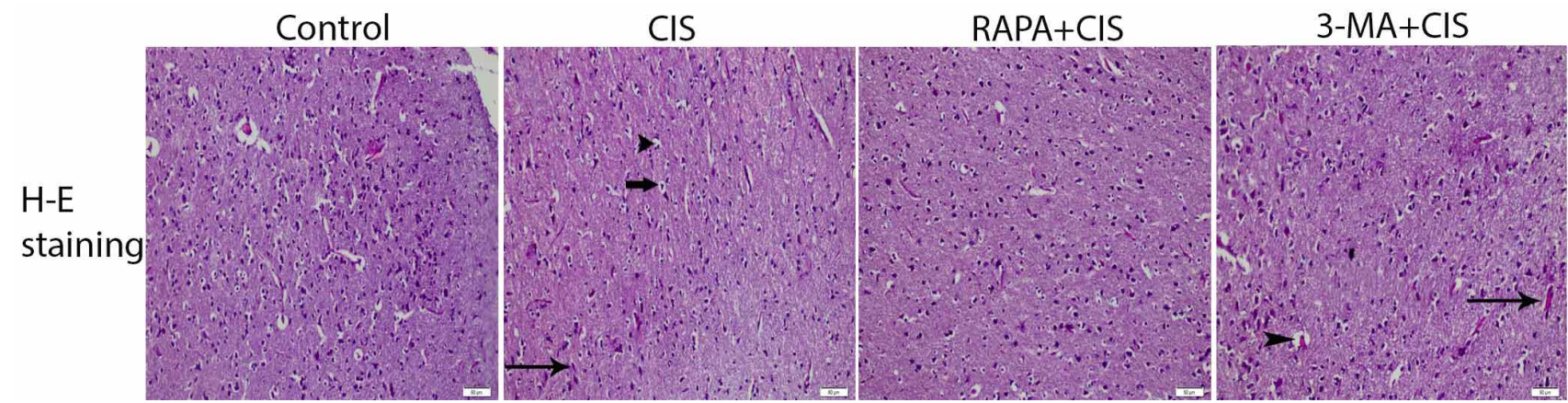

Fig. 1. H\&E staining results. In the Control and RAPA+CIS groups is seen healthy brain tissue. The following structures were seen pathologically in the CIS group; necrotic cells is indicated by thin arrow, pycnotic nuclei is indicated by thick arrow and perineural edema is indicated by arrow head. X200. H\&E: Hematoxylin-Eosin, CIS: Cisplatin, RAPA: Rapamycin, 3-MA: 3-methyladenine 
Immunohistochemistry results. Immunohistochemical staining was performed by using the avidin-biotin method to determine the brain tissue expressions of eNOS, iNOS, nNOS and MAP-2 (Table II, Fig. 2). There was a statistically significant increase in eNOS, iNOS and nNOS staining area in the CIS and 3-MA+CIS groups compared to the Control group. (p<0.0005) (Table I, Fig. 2). In the CIS and 3-MA+CIS groups, MAP-2 staining area significantly decreased compared to the Control and RAPA+CIS groups $(\mathrm{p}<0.003)$.

\section{Biochemical Results}

Brain Tissue Antioxidant Enzymes Activities. The results of the antioxidant enzymesare shown in Table II. SOD and CAT level decreased significantly in the CIS group compared to the Control group ( $\mathrm{p}<0.005)$. MDA level significantly increased in the CIS group compared to the Control group $(p<0.0001)$. MDA level was significantly decreased in the RAPA+CIS group compared to the CIS group $(\mathrm{p}<0.0001)$.

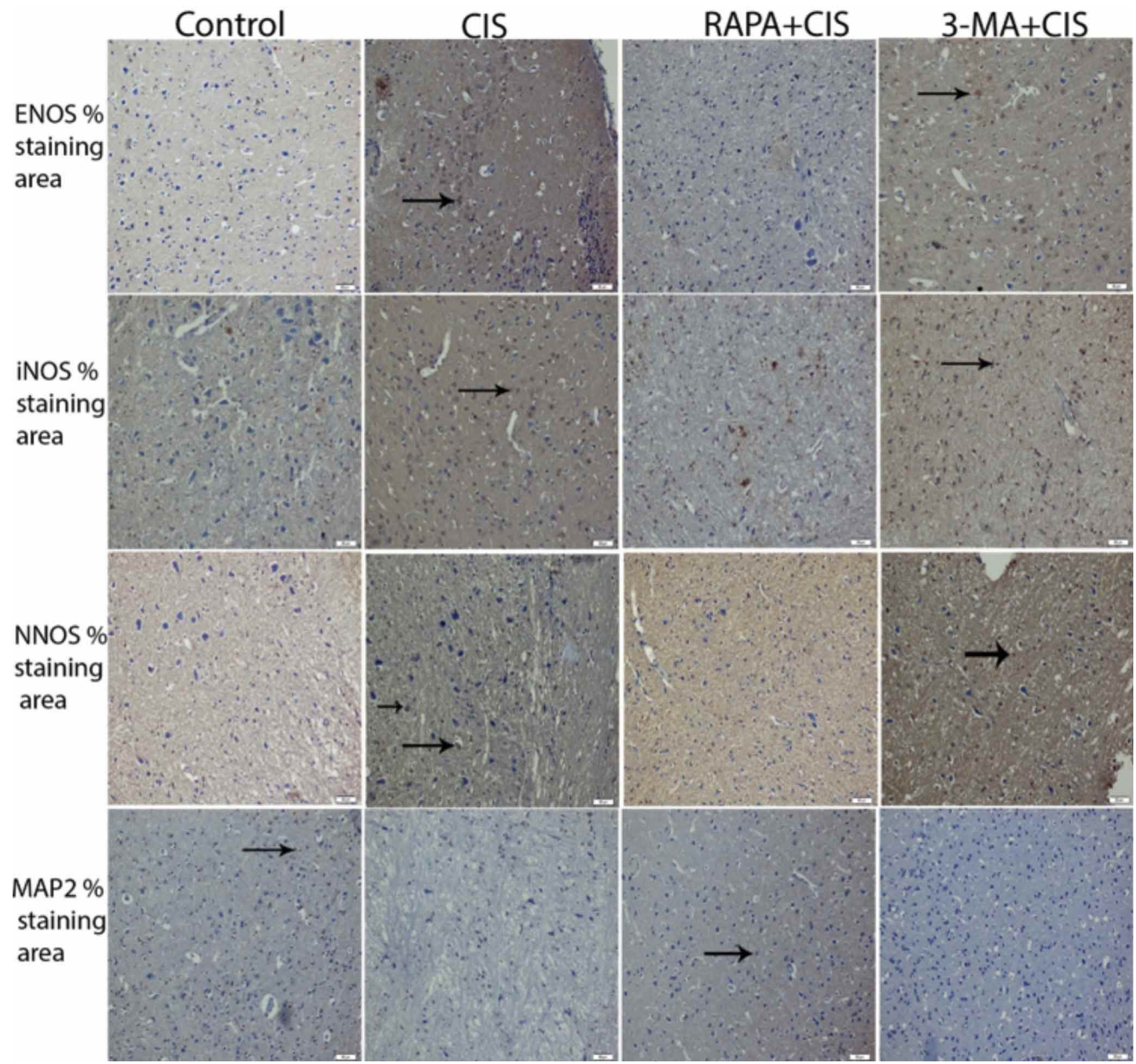

Fig. 2. Results of eNOS, iNOS, nNOS andMAP 2immunohistochemical staining of brain tissues in experimental groups. Immunoreactive areas are indicated by arrows. X200.

CIS: Cisplatin, RAPA: Rapamycin, 3-MA: 3methyladenine, MAP 2: Microtubule associated protein 2, ENOS: Endothelial Nitric oxide synthase, iNOS: inducible Nitric oxide synthase, nNOS: neuronal Nitric oxide synthase. 
Table I. Immunohistochemistry data on the brain tissues.

\begin{tabular}{cccccc}
\hline Groups & $\begin{array}{c}\text { Control } \\
(\mathrm{n}=10)\end{array}$ & $\begin{array}{c}\text { CIS } \\
(\mathrm{n}=10)\end{array}$ & $\begin{array}{c}\text { RAPA+CIS } \\
(\mathrm{n}=10)\end{array}$ & $\begin{array}{c}3-\mathrm{MA}+\mathrm{CIS} \\
(\mathrm{n}=10)\end{array}$ & $p$ \\
\hline eNOS \% staining area & $0.37 \pm 0.15^{\mathrm{a}}$ & $2.52 \pm 1.59^{\mathrm{b}}$ & $0.47 \pm 0.16^{\mathrm{a}}$ & $2.23 \pm 1.89^{\mathrm{b}}$ & 0.0001 \\
iNOS \% staining area & $0.86 \pm 0.53^{\mathrm{a}}$ & $2.07 \pm 0.91^{\mathrm{bc}}$ & $1.44 \pm 0.81^{\mathrm{ac}}$ & $2.57 \pm 1.83^{\mathrm{b}}$ & 0.0004 \\
nNOS \% staining area & $0.25 \pm 0.21^{\mathrm{a}}$ & $1.42 \pm 0.61^{\mathrm{b}}$ & $0.86 \pm 0.97^{\mathrm{a}}$ & $1.65 \pm 0.62^{\mathrm{b}}$ & 0.0001 \\
MAP 2 \% staining area & $3.86 \pm 1.57^{\mathrm{a}}$ & $1.76 \pm 0.52^{\mathrm{b}}$ & $3.46 \pm 2.22^{\mathrm{a}}$ & $1.79 \pm 0.73^{\mathrm{b}}$ & 0.003 \\
\hline
\end{tabular}

The data are expressed as mean + standard deviation. $p<0.05$ was accepted as significant. There were no significant differences between the groups expressed with the same letter.CIS: Cisplatin, RAPA: Rapamycin, 3-MA: 3-methyladenine, MAP 2: Microtubule associated protein 2, ENOS: Endothelial Nitric oxide synthase, iNOS: inducible Nitric oxide synthase, nNOS: neuronal Nitric oxide synthase.

Table II. Biochemical data of the experimental groups.

\begin{tabular}{|c|c|c|c|c|c|}
\hline Groups & $\begin{array}{l}\text { Control } \\
(\mathrm{n}=10)\end{array}$ & $\begin{array}{c}\text { CIS } \\
(\mathrm{n}=10)\end{array}$ & $\begin{array}{c}\text { RAPA+CIS } \\
(\mathrm{n}=10)\end{array}$ & $\begin{array}{c}3-\mathrm{MA}+\mathrm{CIS} \\
(\mathrm{n}=10)\end{array}$ & $p$ \\
\hline Tissue SOD ng/ml & $26.07 \pm 6.30 \mathrm{a}$ & $16.1 \pm 2.35 \mathrm{~b}$ & $22.6 \pm 2.84 \mathrm{a}^{\mathrm{b}}$ & $15.45 \pm 1.17 \mathrm{~b}$ & 0.001 \\
\hline Tissue CAT ng/ml & $62.34 \pm 11.42 \mathrm{a}$ & $44.38 \pm 3.38 \mathrm{~b}$ & $58.65 \pm 13.16^{\mathrm{ab}}$ & $44.11 \pm 8.07 \mathrm{~b}$ & 0.035 \\
\hline Tissue MDA Nmol/ml & $6.44 \pm 1.10^{\mathrm{a}}$ & $13.04 \pm 0.89 \mathrm{~b}$ & $8.87 \pm 1.53 \mathrm{a}$ & $13.38 \pm 2.46 \mathrm{~b}$ & 0.0001 \\
\hline Tissue IL6 Pg/ml & $78.17 \pm 8.64 \mathrm{a}$ & $116.20 \pm 8.32 \mathrm{~b}$ & $91.98 \pm 2.23^{\mathrm{ac}}$ & $107.5 \pm 12.82 b^{c}$ & 0.0001 \\
\hline Serum NO $\mu \mathrm{mol} / \mathrm{L}$ & $13.31 \pm 2.40 \mathrm{a}$ & $18.47 \pm 2.10 \mathrm{~b}$ & $13.55 \pm 3.69 \mathrm{a}$ & $18.77 \pm 4.77 \mathrm{~b}$ & 0.005 \\
\hline
\end{tabular}

The data are expressed as mean + standard deviation. $\mathrm{p}<0.05$ was accepted as significant. There were no significant differences between the groups expressed with the same letter. CIS: Cisplatin, RAPA: Rapamycin, 3-MA: 3-methyladenine, SOD: Superoxide dismutase, CAT: Catalase, MDA: Malondialdehyde, IL-6: Interleukin 6NO: Nitric oxide.

Brain Tissue inflammatory marker IL-6 Activity. The results of the inflammatory IL-6are shown in Table II. IL-6 level increased significantly in the CIS group compared to the control group $(\mathrm{p}<0.005)$.

Pre-inflammatory mediator serum NO result. The result of the serum NO are shown in Table II. NO level increased significantly in the CIS group compared to the Control group $(p<0.005)$. NOS level was significantly decreased in the RAPA+CIS group compared to the CIS group ( $\mathrm{p}<0.05$ ).

\section{DISCUSSION}

Cisplatin (CIS) is an important anti-carcinogenic drug that has been used in many types of cancer in the clinic for years (Uchino et al., 2005; Chiou et al., 2018). Although CIS is used as an anticancer drug, it causes nephrotoxicity, ototoxicity, liver toxicity and neurotoxicity (Abdel Moneim, 2014). Deoxyribonucleic acid (DNA) is the primary goal of CIS. It achieves this by restricting DNA replication (Abdel Moneim). It is not known whether Rapamycin and 3Methyladenine reduce the neurotoxicity caused by cisplatin. Cis increases the oxidative stress and changes cell function and structure (Almutairi et al., 2017). Studies have shown that when CIS is applied, it causes neuronal dysfunction and damage by increasing brain damage such as necrotic cell, apoptotic cell, pycnotic nucleus, and shrunken neuron (Abdel
Moneim; Salman et al., 2015). In the current study, it was observed in the CIS group that necrotic cell, pycnotic nucleus and perineural edema occurred in brain tissue when cis was applied. A brain tissue close to Control was seen in the RAPA + CIS group. The 3-MA + CIS group appeared to be similar to the brain tissue CIS group. Rapamycin (RAPA) is a drug used in many diseases and plays a role in processes such as cell growth, proliferation, protein synthesis and autophagy. It is said that RAPA will be therapeutically useful in neurodegenerative diseases (Bove et al., 2011). Rapamycin has been shown to reduce neurodegeneration and neuronal cell death and improve memory (Bove et al.; Saliba et al., 2017). In the study, it was aimed to reveal the role of NOS enzymes in CIS-induced damage in the brain tissues applied RAPA and 3-MA.

The free radical nitric oxide (NO) is designed as an important physiological mediator in the brain. $\mathrm{NO}$ in the brain is mainly produced by NOSs (iNOS, eNOS, nNOS) (Lu et al., 2015) NO is produced in cells of different tissues and is a pre-inflammatory mediator involved in different biological processes. It plays a role in regulating blood pressure (Yoon et al., 2017). nNOS was first obtained from neurons. eNOS is found in both endothelial cells and neurons. Constitutive nNOS and eNOS are low-output enzymes that produce NO that are not involved in physiological signaling. Expressed in the brain, iNOS is a high-output enzyme that produces NO, which contributes to cellular damage in various immunological disorders (Cioni et al., 2019). 
The cytotoxicity of anticancer drugs has been reported to lead to excessive NO production (Mansour et al., 2006). The amount of NO increases following the increased NOS amount with the CIS injection (Curran et al., 1991). NO, iNOS, eNOS and nNOS levels have been shown to increase significantly in both CIS application and other brain injury studies (Fang et al.; Qin et al.; N et al., 2019). CIS application has been shown to increase NO in different tissues along with oxidative stress in liver, kidney and brain tissue (Elberry et al., 2013; N et al.; Omar et al., 2016). In the current study, the level of iNOS, eNOS and nNOS immunreactivity in the CIS applied group showed a significant increase compared to the Control group. NOS enzyme levels may have increased due to excess ROS in the tissue after CIS application. This can trigger neuronal cell dysfunction.

In the group treated with RAPA, the immunoreactivity of these three enzymes decreased. Chronic RAPA administration has been shown to be effective in restoring functional activity by correcting brain vascular integrity through NOS and inducing eNOS synthesis and NO release in the brain (Lin et al., 2013). In our study, the closest result to the control group is eNOS expression. Therefore, NOS values decreased after giving CIS to the RAPA group.We can conclude that RAPA provides this possible healing effect by reducing the level of NOS enzyme. Because we found the NOS enzyme levels of the rapa group close to the control group.

However, we found that this enzyme immunreactivity increased in groups treated with 3-MA. In autophagy, 3-MA inhibits autophagosome elongation and shows an inhibitory effect (Caldeira et al., 2014). Autophagy is known as one of the cell death mechanisms. It occurs under conditions such as stress and hunger in the cell. It has been reported that 3-MA relieves cognitive impairment by suppressing autophagy in the rat hippocampus (Zhao et al., 2019). Considering the autophagy inhibiting effect of 3-MA, it did not cause any change in NOS enzyme levels after CIS administration. NOS enzyme expression is not statistically different in CIS and 3MA + CIS groups. In this case, we think that 3-MA is not very effective under the toxic effect of CIS. Because while NOS enzyme levels in the Rapa + CIS group were close to control, no change was observed in the 3-MA-CIS group. These results show that Rapa is more effective at NOS levels against CIS toxicity in brain tissue.

Increasing NOS expressions in the tissue led to an increase in the NO amount in the CIS group when we evaluate the serum. These results indicate that RAPA administration will reduce the level of molecules associated with inflammation in CIS-induced brain tissue and have a neuroprotective effect (Su et al., 2014; Saliba et al.).
Microtubule associated protein 2 (MAP 2) helps maintain neuronal morphology by providing microtubule stabilization (Xie et al., 2014). Various studies show that MAP 2 level decreases in brain degeneration (Takahashi et al., 2013; Yu et $a l$.). However, the NOS level has been shown to increase in brain damage (Fang et al.). We found that the MAP2 level decreased in the CIS group, in contrast to the increasing NOS level in this damage. In the RAPA + CIS group, there was a significant increase in MAP2 level compared to the CIS group. There was no change in the group treated with 3-MA. In line with other studies, RAPA appears to significantly reduce the level of neurodegeneration by maintaining the MAP 2 level (Brewster et al., 2013; Kolosova et al., 2013). RAPA corrected expression level of MAP 2 in parallel with the improvement in NOS enzymes level.

One of the toxic effects of CIS is the release of proinflammatory cytokines (Jaggi \& Singh, 2012). CIS increases neuroinflammation. Among proinflammatory cytokines, IL-6 is a very strong and large cytokine and affects other cytokines.CIS increases both brain tissue and serum IL-6 levels (Abdel-Wahab \& Moussa, 2019; Chen et al.). It has been reported that increased NOS level increases pre-inflammatory IL-6 level (Yuan et al., 2020). In our study, IL-6 level in brain tissue in the CIS group showed a significant increase compared to the Control group. RAPA reduces the level of IL-6 in CIS-induced neurotoxicity. We can say that RAPA decreases IL-6 level and decreases inflammation and is compatible with other studies (Saliba et al.; Cappoli et al.).

Oxidative stress leads to lipid peroxidation (LPO) in the cell through the production of reactive oxygen species (ROS) (Rana et al., 2019). The endogenous antioxidant system (glutathione peroxidase, superoxide dismutase, catalase) aims to neutralize ROS.However, excess ROS produced consumes endogenous antioxidants and leads to peroxidation of membrane lipids and increases the oxidation of proteins (Kumar et al., 2015). There are many studies showing that oxidative stress and LPO play a role in CIS-induced neurotoxicity (Hassan et al., 2013; Waseem \& Parvez, 2013). In the current study, SOD and CAT levels in brain tissue showed a significant decrease in CIS group compared to the Control group. In contrast, the level of MDA for brain tissue LPO increased significantly in the CIS group compared to the Control group. The decrease in antioxidant capacity led to an increase in LPO level.An increase in the amount of antioxidants occurred in the group treated with RAPA. it was also observed that there was a decrease in LPO level. Oxidative stress and inflammation are said to be interdependent mechanisms in CIS-induced neurotoxicity. Excessive ROS amount accelerates the release of proinflammatory cytokines (Akman et al., 2015; Abdel-Wahab \& Moussa). Increased lipid peroxidation and decreased antioxidant capacity may develop due to the increase in NOS level. 
As a result, in our study, we evaluated the effect of autophagy activators and inhibitors on CIS-induced neurotoxicity through NOSs.An increase in the amount of NOS occurred due to the increase of oxidative stress. This led to brain damage. In the case of brain damage, a decrease in MAP2 level was observed. Likewise, pre-inflammatory marker IL-6 and lipid peroxidation end product MDA level increased in brain damage, while antioxidant enzymes such as SOD and CAT decreased. We observed that CIS induced neurodegeneration was reduced by NOSs with RAPA therapy. Based on these results, RAPA can serve as a complementary therapeutic agent with cis. For this, it should be taken into consideration in pre-clinical research.

ACKNOWLEDGMENTS. This project was supported by Erciyes University Scientific Research Projects Unit (TSA2019-8792).

KAYMAK, E.; KARABULUT, D.; OZTURK, E.; AKIN, A. T. \& YAKAN, B. Efectos de la rapamicina y la 3-metiladenina sobre la enzima óxido nítrico sintasa en la neurotoxicidad inducida por cisplatino. Int. J. Morphol., 39(2):659-666, 2021.

RESUMEN: El objetivo de este estudio fue determinar la relación de la rapamicina potenciadora de la autofagia (RAPA) y el inhibidor de la autofagia 3-metiladenina (3-MA) con óxido nítrico sintasas (NOS) en la neurotoxicidad inducida por cisplatino (CIS) en ratas. Las ratas se dividieron en 4 grupos $(n=10)$ : grupo control se aplicó solución salina, CIS (una dosis única de $8 \mathrm{mg} / \mathrm{kg}$ intraperitoneal (ip) el día 7 del experimento), RAPA + CIS ( 2 mg / $\mathrm{kg}$ / ipRAPA por día y $8 \mathrm{mg} / \mathrm{kg} /$ ip CIS el día 7), 3-MA + CIS (15 $\mathrm{mg} / \mathrm{kg} /$ ip 3-MA por día y $8 \mathrm{mg} / \mathrm{kg} /$ ip CIS el día 7). Las ratas se sacrificaron bajo anestesia y los tejidos cerebrales fueron analizados histopatológicamente. Se realizaron inmunotinciones con eNOS, Inos, nNOS y MAP 2 para determinar los niveles de expresión de estas proteínas entre los grupos. Se midieron los niveles de superóxido dismutasa (SOD), catalasa (CAT), malondialdehído (MDA) e interleucina IL-6 en el tejido cerebral y el nivel de óxido nítrico (NO) en suero mediante ensayo ELISA. En la evaluación histopatológica, se observó neurodegeneración en el grupo CIS. Hubo un aumento en la inmunotinción de eNOS, iNOS y nNOS en el grupo CIS. Mientras que la inmunotinción de MAP2 del grupo CIS disminuyó. Hubo una disminución en los niveles de SOD y CAT del tejido cerebral en el grupo CIS, sin embargo, hubo un aumento en los niveles de MDA, IL-6 y NO en el tejido cerebral en el grupo CIS. Observamos que la capacidad antioxidante aumentó, mientras que la inflamación y los niveles de óxido nítrico disminuyeron en el grupo tratado con RAPA. 3-MA no tiene un efecto significativo. Sugerimos que la neurotoxicidad inducida por CIS es más eficaz que Rapa 3-MA y también puede estar relacionada con las enzimas NOS.

PALABRAS ClaVE: Antioxidante; Cisplatino; Rapamicina; 3-metiladenina; Óxido nítrico.

\section{REFERENCES}

Abdel-Wahab, W. M. \& Moussa, F. I. Neuroprotective effect of N-acetylcysteine against cisplatin-induced toxicity in rat brain by modulation of oxidative stress and inflammation. Drug Des. Devel. Ther, 13:1155-62, 2019.

Abdel Moneim, A. E. Azadirachta indica attenuates cisplatin-induced neurotoxicity in rats. Indian J. Pharmacol., 46(3):316-21, 2014.

Akman, T.; Akman, L.; Erbas, O.; Terek, M. C.; Taskiran, D. \& Ozsaran, A. The preventive effect of oxytocin to Cisplatin-induced neurotoxicity: an experimental rat model. Biomed. Res. Int., 2015:167235, 2015.

Almutairi, M. M.; Alanazi, W. A.; Alshammari, M. A.; Alotaibi, M. R.; Alhoshani, A. R.; Al-Rejaie, S. S.; Hafez, M. M. \& Al-Shabanah, O. A. Neuro-protective effect of rutin against Cisplatin-induced neurotoxic rat model. BMC Complement. Altern. Med., 17:472, 2017.

Bove, J.; Martínez-Vicente, M. \& Vila, M. Fighting neurodegeneration with rapamycin: mechanistic insights. Nat. Rev. Neurosci., 12(8):437-52, 2011.

Brewster, A. L.; Lugo, J. N.; Patil, V. V.; Lee, W. L.; Qian, Y.; Vanegas, F. \& Anderson, A. E. Rapamycin reverses status epilepticus-1nduced memory deficits and dendritic damage. PLoS One, 8(3):e57808, 2013.

Caldeira, M. V.; Salazar, I. L.; Curcio, M.; Canzoniero, L. M. T. \& Duarte, C. B. Role of the ubiquitin-proteasome system in brain ischemia: friend or foe? Prog. Neurobiol., 112:50-69, 2014.

Cao, S.; Shrestha, S.; Li, J.; Yu, X.; Chen, J.; Yan, F.: Ying, G.; Gu, C.; Wang, L. $\&$ Chen, G. Melatonin-mediated mitophagy protects against early brain injury after subarachnoid hemorrhage through inhibition of NLRP3 inflammasome activation. Sci. Rep., 7(1):2417, 2017.

Cappoli, N.; Mezzogori, D.; Tabolacci, E.; Coletta, I.; Navarra, P.; Pani, G. \& Dello Russo, C. (2019). The mTOR kinase inhibitor rapamycin enhances the expression and release of pro-inflammatory cytokine interleukin 6 modulating the activation of human microglial cells. EXCLI J., 18:779-98, 2019.

Hanif, M. \& Hartinger, C. G. Anticancer metallodrugs: where is the next cisplatin? Future Med. Chem., 10(6):615-7, 2018

Chen, C.; Zhang, H.; Xu, H.; Zheng, Y.; Wu, T. \& Lian, Y. Ginsenoside Rb1 ameliorates cisplatin-induced learning and memory impairments. J. Ginseng Res., 43(4):499-507, 2019.

Chiou, C. T.; Wang, K. C.; Yang, Y. C.; Huang, C. L.; Yang, S. H.; Kuo, Y. H. \& Huang, N. K. Liu Jun Zi Tang-A potential, multi-herbal complementary therapy for chemotherapy-induced neurotoxicity. Int. J. Mol. Sci., 19(4):1258, 2018.

Cioni, C.; Angiulli, E. \& Toni, M. Nitric oxide and the neuroendocrine control of the osmotic stress response in teleosts. Int. J. Mol. Sci., 20(3):489, 2019.

Curran, R. D.; Ferrari, F. K.; Kispert, P. H.; Stadler, J.; Stuehr, D. J.; Simmons, R. L. \& Billiar, T. R. Nitric oxide and nitric oxide-generating compounds inhibit hepatocyte protein synthesis. FASEB J., 5(7):2085-92, 1991.

Dasari, S. \& Tchounwou, P. B. Cisplatin in cancer therapy: molecular mechanisms of action. Eur. J. Pharmacol., 740:364-78, 2014.

Elberry, A. A.; Refaie, S. M.; Kamel, M.; Ali, T.; Darwish, H. \& Ashour, O. Oxytocin ameliorates cisplatin-induced nephrotoxicity in Wistar rats. Ann. Saudi Med., 33(1):57-62, 2013.

Fang, X.; Li, Y.; Qiao, J.; Guo, Y. \& Miao, M. Neuroprotective effect of total flavonoids from Ilex pubescens against focal cerebral ischemia/reperfusion injury in rats. Mol. Med. Rep., 16(5):7439-49, 2017.

Fontaine-Lenoir, V.; Chambraud, B.; Fellous, A.; David, S.; Duchossoy, Y.; Baulieu, E. E. \& Robel, P. Microtubule-associated protein 2 (MAP2) is a neurosteroid receptor. Proc. Natl. Acad. Sci. U. S. A., 103(12):4711-6, 2006.

Hassan, I.; Chibber, S.; Khan, A. A. \& Naseem, I. Cisplatin-induced neurotoxicity in vivo can be alleviated by riboflavin under photoillumination. Cancer Biother. Radiopharm., 28(2):160-8, 2013.

He, H. Y.; Ren, L.; Guo, T. \& Deng, Y. H. Neuronal autophagy aggravates microglial inflammatory injury by downregulating CX3CL1/fractalkine after ischemic stroke. Neural Regen. Res., 14(2):280-8, 2019.

Jaggi, A. S. \& Singh, N. Mechanisms in cancer-chemotherapeutic drugs-induced peripheral neuropathy. Toxicology, 291(1-3):1-9, 2012.

Jin, Y.; Wang, R.; Yang, S.; Zhang, X. \& Dai, J. Role of microglia autophagy in microglia activation after traumatic brain injury. World Neurosurg., 100:35160, 2017.

Karabulut, D.; Ulusoy, H. B.; Kaymak, E. \& Sönmez, M. F. Therapeutic effects of pentoxifylline on diabetic heart tissue via NOS. Anatol. J. Cardiol., 16(5):310-5, 2016. 
Kohsaka, T.; Minagawa, I.; Morimoto, M.; Yoshida, T.; Sasanami, T.; Yoneda, Y.; Ikegaya, N. \& Sasada, H. Efficacy of relaxin for cisplatin-induced testicular dysfunction and epididymal spermatotoxicity. Basic Clin. Androl., 30:3, 2020.

Kolosova, N. G.; Vitovtov, A. O.; Muraleva, N. A.; Akulov, A. E.; Stefanova, N. A. \& Blagosklonny, M. V. Rapamycin suppresses brain aging in senescence-accelerated OXYS rats. Aging (Albany NY), 5(6):474-84, 2013.

Kumar, A.; Sasmal, D. \& Sharma, N. An insight into deltamethrin induced apoptotic calcium, p53 and oxidative stress signalling pathways. Toxicol. Environ. Health Sci., 7:25-34, 2015.

Li, J. R.; Xu, H. Z.; Nie, S.; Peng, Y. C.; Fan, L. F.; Wang, Z. J.; Wu, C.; Yan, F.; Chen, J. Y.; Gu, C.; et al. Fluoxetine-enhanced autophagy ameliorates early brain injury via inhibition of NLRP3 inflammasome activation following subrachnoid hemorrhage in rats. J. Neuroinflammation, 14(1):186, 2017.

Lin, A. L.; Zheng, W.; Halloran, J. J.; Burbank, R. R.; Hussong, S. A.; Hart, M. J.; Javors, M.; Shih, Y. Y. I.; Muir, E.; Fonseca, R. S.; et al. Chronic rapamycin restores brain vascular integrity and function through NO synthase activation and improves memory in symptomatic mice modeling Alzheimer's disease. J. Cereb. Blood Flow Metab., 33(9):1412-21, 2013.

Lu, Q.; Harris, V. A.; Rafikov, R.; Sun, X.; Kumar, S. \& Black, S. M. Nitric oxide induces hypoxia ischemic injury in the neonatal brain via the disruption of neuronal iron metabolism. Redox Biol., 6:112-21, 2015.

Lu, Y. \& Cederbaum, A. I. Cisplatin-induced hepatotoxicity is enhanced by elevated expression of cytochrome P450 2E1. Toxicol. Sci., 89(2):515-23, 2006.

Mansour, H. H.; Hafez, H. F. \& Fahmy, N. M. Silymarin modulates Cisplatininduced oxidative stress and hepatotoxicity in rats. J. Biochem. Mol. Biol., 39(6):656-61, 2006.

Melli, G.; Taiana, M.; Camozzi, F.; Triolo, D.; Podini, P.; Quattrini, A.; Taroni, F. \& Lauria, G. Alpha-lipoic acid prevents mitochondrial damage and neurotoxicity in experimental chemotherapy neuropathy. Exp Neurol, 214(2):276-84, 2008

N, S. V.; Mohamad, A. \& Razdan, R. Allantoin attenuates deficits of behavioural and motor nerve conduction in an animal model of cisplatin-induced neurotoxicity in rats. Animal Model Exp. Med., 2(2):114-20, 2019.

Omar, H. A.; Mohamed, W. R.; Arab, H. H. \& Arafa, E. S. A. Tangeretin alleviates cisplatin-1nduced acute hepatic injury in rats: targeting MAPKs and apoptosis. PLoS One, 11(3):e0151649, 2016

Park, S. B.; Krishnan, A. V.; Lin, C. S. Y.; Goldstein, D.; Friedlander, M. \& Kiernan, M. C. (2008). Mechanisms underlying chemotherapy-induced neurotoxicity and the potential for neuroprotective strategies. Curr. Med. Chem., 15(29):3081-94, 2008.

Pérez-Corredor, P. A.; Gutiérrez-Vargas, J. A.; Ciro-Ramírez, L.; Balcazar, N. \& Cardona-Gómez, G. P. High fructose diet-induced obesity worsens postischemic brain injury in the hippocampus of female rats. Nutr. Neurosci., $1-15,2020$.

Qin, Y.; Hu, W.; Yang, Y.; Hu, Z.; Li, W. \& Fang, M. Neuroprotective effect of DAHP via antiapoptosis in cerebral ischemia. Behav. Neurol., 2018:5050469, 2018

Quintanilha, J. C. F.; de Sousa, V. M.; Visacri, M. B.; Amaral, L. S.; Santos, R. M. M.; Zambrano, T.: Salazar, L. A. \& Moriel, P. Involvement of cytochrome P450 in cisplatin treatment: implications for toxicity. Cancer Chemother. Pharmacol., 80(2):223-33, 2017.

Raber, J.; Torres, E. R. S.; Akinyeke, T.; Lee, J.; Weber Boutros, S. J.; Turker, M. S. \& Kronenberg, A. Detrimental effects of helium 1on irradiation on cognitive performance and cortical levels of MAP-2 in B6D2F1 mice. Int. J. Mol. Sci., 19(4):1247, 2018.

Rana, A.; Singh, S.; Sharma, R. \& Kumar, A. Traumatic brain injury altered normal brain signaling pathways: implications for novel therapeutics approaches. Curr. Neuropharmacol., 17(7):614-29, 2019.

Saliba, S. W.; Vieira, E. L. M.; de Melo Santos, R. P.; Candelario-Jalil, E.; Fiebich, B. L.; Vieira, L. B.; Teixeira, A. L. \& de Oliveira, A. C. P. Neuroprotective effects of intrastriatal injection of rapamycin in a mouse model of excitotoxicity induced by quinolinic acid. J. Neuroinflammation, 14(1):25, 2017.

Salman, M.; Naseem, I.; Hassan, I.; Khan, A. A. \& Alhazza, I. M. Riboflavin arrests cisplatin-1nduced neurotoxicity by ameliorating cellular damage in dorsal root ganglion cells. Biomed. Res. Int., 2015:603543, 2015.

Santos, N. A. G.; Catão Bezerra, C. S.; Martins, N. M.; Curti, C.; Bianchi, M. L. P. \& Santos, A. C. Hydroxyl radical scavenger ameliorates cisplatin- induced nephrotoxicity by preventing oxidative stress, redox state unbalance, impairment of energetic metabolism and apoptosis in rat kidney mitochondria. Cancer Chemother. Pharmacol., 61(1):145-55, 2008.

Schmitz, F.; Heit, A.; Dreher, S.; Eisenächer, K.; Mages, J.; Haas, T.; Krug, A.; Janssen, K. P.; Kirschning, C. \& Wagner, H. Mammalian target of rapamycin (mTOR) orchestrates the defense program of innate immune cells. Eur. J. Immunol., 38(11):2981-92, 2008.

$\mathrm{Su}, \mathrm{W} . ; \mathrm{Li}, \mathrm{Z}$.; Jia, Y. \& Zhuo, Y. Rapamycin is neuroprotective in a rat chronic hypertensive glaucoma model. PLoS One, 9(6):e99719, 2014.

Takahashi, R. H.; Capetillo-Zarate, E.; Lin, M. T.; Milner, T. A. \& Gouras, G. $\mathrm{K}$. Accumulation of intraneuronal b-amyloid 42 peptides is associated with early changes in microtubule-associated protein 2 in neurites and synapses. PLoS One, 8(1):e51965, 2013.

Uchino, H.; Matsumura, Y.; Negishi, T.; Koizumi, F.; Hayashi, T.; Honda, T.; Nishiyama, N.; Kataoka, K.; Naito, S. \& Kakizoe, T. Cisplatin-incorporating polymeric micelles (NC-6004) can reduce nephrotoxicity and neurotoxicity of cisplatin in rats. Br. J. Cancer, 93(6):678-87, 2005

Unel, C. C. \& Erol, K. The role of ionic homeostasis in cisplatin-1nduced neurotoxicity: a preliminary study. Eurasian J. Med., 50(2):81-5, 2018.

Waseem, M. \& Parvez, S. Mitochondrial dysfunction mediated cisplatin induced toxicity: modulatory role of curcumin. Food Chem. Toxicol., 53:334-42, 2013.

Xie, C.; Miyasaka, T.; Yoshimura, S.; Hatsuta, H.; Yoshina, S.; Kage-Nakadai, E.; Mitani, S.; Murayama, S. \& Ihara, Y. The homologous carboxyl-terminal domains of microtubule-associated protein 2 and TAU induce neuronal dysfunction and have differential fates in the evolution of neurofibrillary tangles. PLoS One, 9(2):e89796, 2014.

Xu, X.; Zhi, T.; Chao, H.; Jiang, K.; Liu, Y.; Bao, Z.; Fan, L.; Wang, D.; Li, Z.; Liu, N.; et al. ERK1/2/mTOR/Stat3 pathway-mediated autophagy alleviates traumatic brain injury-induced acute lung injury. Biochim. Biophys. Acta Mol. Basis Dis., 1864(5 Pt. A):1663-74, 2018.

Xu, Y.; Yang, S.; Huang, J.; Ruan, S.; Zheng, Z. \& Lin, J. Tgf-b1 induces autophagy and promotes apoptosis in renal tubular epithelial cells. Int. J. Mol. Med., 29(5):781-90, 2012.

Yoon, N.; Na, K. \& Kim, H. S. Simulated weightlessness affects the expression and activity of neuronal nitric oxide synthase in the rat brain. Oncotarget, 8(19):30692-9, 2017.

Yu, X.; Guan, Q.; Wang, Y.; Shen, H.; Zhai, L.; Lu, X. \& Jin, Y. Anticonvulsant and anti-apoptosis effects of salvianolic acid B on pentylenetetrazolekindled rats via AKT/CREB/BDNF signaling. Epilepsy Res., 154:90-6, 2019

Yuan, J.; Hou, K.; Yao, Y.; Du, Z.; Lu, C.; Yuan, Q. \& Gao, X. Gold clusters attenuate inflammation in rat mesangial cells via inhibiting the activation of NF-kB pathway. Nanomaterials (Basel), 10(4):712, 2020.

Zhao, L.; Zhang, B.; Cui, Y.; Hou, C.; Zeng, Q.; Gao, T.; Zhang, Z.; Yu, J.; Wang, Y.; Wang, A.; et al. 3-Methyladenine alleviates excessive iodineinduced cognitive impairment via suppression of autophagy in rat hippocampus. Environ. Toxicol., 34(8):912-20, 2019.

Zuo, G.; Zhang, D.; Mu, R.; Shen, H.; Li, X.; Wang, Z.; Li, H. \& Chen, G. Resolvin D2 protects against cerebral ischemia/reperfusion injury in rats. Mol. Brain, 11:9, 2018.

Corresponding author:

Emin Kaymak

Yozgat Bozok University

Faculty of Medicine

Histology and Embryology Department

Yozgat - TURKEY

E-mail: e_kaymak@hotmail.com

Orcid ID of Emin KAYMAK 0000-0002-3818-2693

Received: 15-06-2020

Accepted: 06-12-2020 